\title{
Zum Geleit.
}

Heute, ein Jahr nach Beendigung des Moskauer Turniers, über dessen Bedeutung zu sprechen, mag etwas verspätet erscheinen. Aber diese Ansicht ist wohl nur auf den ersten Blick begründet. Denn ungeachtet dessen, da $\beta$ ein derart großer Zeitraum in die Lande gegangen ist, hat nach dem Moskauer Turnier kein auch nur annähernd so starkes stattgefunden.

Die zweite Begegnung zwischen Capablanca und Lasker (nach 1921), die, individuell betrachtet, mit einem Unentschieden und, der Turniertabelle nach, mit einem Siege Laskers endete, bildet immer noch die letzte Phase des Zweikampfes dieser Titanen. Seitdem haben sie die Klingen nicht mehr miteinander gekreuzt und der Streit ihrer Anhänger ist auch heute noch nicht entschieden. Lasker, der zweimal (New York und Moskau) über Capablanca obgesiegt hat, verbleibt trotzdem nur Ex-Weltmeister, während Capablanca seinerseits bewiesen hat, daß er dasselbe Anrecht auf die Weltmeisterschaft besitzt wie vor dem Turnier.

Der überaus glänzende Erfolg Bogoljubows beweist, daß neben Lasker und Capablanca junge, gefährliche Anwärter auf den Schachthron erstanden sind. Wie das Alter sich andrerseits siegreich zu verteidigen weiß, lehrt das Beispiel Torres, der ja schließlich doch von Marshall überholt wurde.

Das wären die sportlichen Errungenschaften unsres Turniers, Errungenschaften, an die weder die brillanten Siege Aljechins, noch die Erfolge Nimzowitschs auch nur im entferntesten heranreichen.

Daneben hat für uns das Moskauer Turnier noch eine ganz andere eine politische Bedeutung. Wie das Drum und Dran auch sein mag, Tatsache ist und bleibt: Moskau war für einen Monat lang der Brennpunkt des Interesses, der Mittelpunkt, der die Blicke vieler Tausende, wenn nicht Millionen von Schachspielern auf sich lenkte. Der armseligste Kleinbürger, der unansehnlichste Schächer irgendeines Krähwinkels der bürgerlichen Welt sah, staunte und mußte zugeben, daß kein auf seine Kultur noch so 
erpichter westeuropäischer, bürgerlicher Staat das zuwege gebracht hat, was die junge Sowjetunion getan. Das blieb natürlich nicht ohne Einfluß auf die Vorstellung, die man sich von Moskau und Rußland machte und macht.

Die schwere Zeit gestattet uns augenblicklich nicht, das Turnier zu wiederholen, aber wir glauben, im Laufe der nächsten Jahre dazu in der Lage zu sein. Auf alle Fälle können die Schachfreunde aller Länder versichert sein, daß wir alles in unsern Kräften Stehende tun werden.

N. Krylenko. 